\title{
PENGEMBANGAN PUSAT BISNIS (CENTRAL BUSINESS DISTRICT) DENGAN POLA KERJASAMA PEMERINTAH-SWASTA (KASUS WILAYAH KAKI SURAMADU SISI SURABAYA)
}

\author{
M. Ikhsan Setiawan ${ }^{1}$, Agus Sukoco ${ }^{2}$ \\ ${ }^{I}$ M. Ikhsan Setiawan, Universitas Narotama,ikhsan.setiawan@narotama.ac.id \\ ${ }^{2}$ Agus Sukoco, Universitas Narotama,agus.sukoco@narotama.ac.id
}

\begin{abstract}
ABSTRAK
Anggaran infrastruktur mencapai Rp 290 Trilyun dalam APBN-P (Anggaran Pendapatan Belanja NegaraPerubahan) tahun 2015 menjadi peluang tersediri bagi pengembangan bisnis properti, adanya pengembangan infrastruktur akan memicu peningkatan bisnis properti di daerah. Bursa Efek Indonesia tahun 2014 mencatat nilai kapitalisasi pasar (market cap) untuk sektor properti, real estate, dan konstruksi gedung mencapai Rp 360 Trilyun (BEI, 2014). Survey Bank Indonesia menunjukkan peningkatan signifikan dalam harga jual unit strata title di Jabodetabek, Banten dan Bandung segmen perkantoran, ritel, kondominium dan lahan industri, serta peningkatan tarif sewa properti komersial dan tarif hotel bintang 3, 4 dan 5 (BI, 2014). Otonomi daerah melalui Undang-undang nomor 22/1999 dan nomor 34/2004 menuntut pemerintah propinsi, kabupaten dan kota kreatif meningkatkan pendapatan daerah. APBD (Anggaran Pendapatan Belanja Daerah) tahun 2013 defisit keuangan daerah mencapai Rp 54,217 Trilyun (Kemendagri, 2013). Pengembangan bisnis properti daerah dapat berupa kolaborasi antara Pemerintah Pusat, Pemerintah Daerah, BUMN, BUMD, dan Swasta. Tujuan penelitian ini menganalisis bisnis properti melalui pola kerjasama pemerintah-swasta dalam pengembangan pusat bisnis seaport-waterfrontcity dengan mengambil studi kasus di area Jembatan Suramadu sisi Surabaya. Analisis dengan HGB 30 tahun dan biaya sewa Rp 500.000,- /m2 per tahun dengan penjualan optimis 100\%, menunjukkan hasil yang layak dengan NPV Rp. 19.251.719.084.088, IRR 18,51\%, PI 1,99 dan PBP 11 tahun.
\end{abstract}

Kata Kunci: Bisnis Properti, Kerjasama Pemerintah-Swasta, Net Present Value

\section{PENDAHULUAN}

Indonesia peringkat kedua investasi global berdasarkan Economist Corporate Network Asia Business Outlook Survey 2014 (Economist, 2015), serta peringkat keempat menurut UNCTAD World Investment Prospect 2013- 2015 (UNCTAD, 2015). Boston Consulting Group menyatakan peningkatan penduduk kelas menengah di Indonesia mencapai 74 juta jiwa (2013) dan 141 juta jiwa (2020) salah satunya mendorong belanja konsumen dalam bentuk pemilikan/investasi properti (Boston Consulting Group, 2013). Badan Koordinasi Penanaman Modal menyatakan realisasi investasi PMDN (Penanaman Modal Dalam Negeri) dan PMA (Penanaman Modal Swasta) sektor konstruksi, perumahan, kawasan industri, perkantoran, hotel dan restoran mengalami peningkatan signifikan sejak tahun 2010, dimana tahun 2014 mencapai Rp. 25,66 trilyun (Badan Koordinasi Penanaman Modal, 2014). Bursa Efek Indonesia mencatat nilai kapitalisasi pasar (market cap) untuk sektor properti, real estate, dan konstruksi gedung mencapai Rp 360 Trilyun (Bursa Efek Indonesia, 2014). Survey Bank Indonesia menunjukkan dalam 3 tahun terakhir terjadi peningkatan yang signifikan dalam harga jual unit strata title di Jabodetabek, Banten dan Bandung untuk segmen perkantoran, ritel, kondominium dan lahan industri, serta peningkatan tarif sewa properti komersial dan tarif hotel bintang 3, 4 dan 5 (Bank Indonesia, 2014). Meningkatnya prospek bisnis properti mendorong pemerintah daerah untuk bekerjasama dengan pihak 
swasta guna memperoleh peningkatan pendapatan daerah. Otonomi daerah melalui Undangundang nomor 22/1999 dan nomor 34/2004 menuntut pemerintah propinsi, kabupaten dan kota kreatif meningkatkan pendapatan daerah, hal tersebut terlihat pada Anggaran Pendapatan Belanja Daerah tahun 2013 dengan defisit keuangan daerah mencapai Rp 54,217 Trilyun (Kementerian Dalam Negeri, 2013). Potensi pendapatan daerah seharusnya mampu menutupi defisit bila melihat laporan neraca pemerintah daerah se-Indonesia pada tahun 2010 terdapat aset tanah pemda senilai Rp 558,456 Trilyun dan aset gedung/bangunan pemda senilai Rp 228,343 Trilyun (Kementerian Dalam Negeri, 2010). Pengembangan bisnis properti daerah dapat berupa kolaborasi antara Pemerintah Pusat, Pemerintah Daerah, BUMN, BUMD, dan Swasta. Public-Private Partnership (Kerjasama Pemerintah-Swasta) menjadi salah satu solusi peningkatan perekonomian daerah dan telah terbukti di beberapa negara tetangga antara lain di Malaysia dan Singapore. Anggaran infrastruktur mencapai Rp 290 Trilyun dalam APBN-P (Anggaran Pendapatan Belanja Negara-Perubahan) tahun 2015 menjadi peluang tersediri bagi pengembangan bisnis properti, disebabkan adanya pengembangan infrastruktur akan memicu peningkatan bisnis properti di wilayah tersebut. BUMD (Badan Usaha Milik Daerah) PT Pembangunan Jaya Ancol Tbk menjadi salah satu model kerjasama pemerintah daerah-swasta yang berhasil mengelola bisnis properti dalam bentuk pusat bisnis daerah (Central Business District) di Ancol, Jakarta (Bursa Efek Indonesia, 2013). Pemilik perusahaan adalah pemda DKI Jakarta (72\%), PT Pembangunan Jaya (18,01\%) dan publik (9,99\%). PT Pembangunan Jaya Ancol Tbk mengelola lahan seluas 500 ha meliputi zona rekreasi (200 ha), zona industri dan zona properti, PT Pembangunan Jaya Ancol Tbk telah memberikan kontribusi yang signifikan tidak hanya bagi perusahaan tetapi juga untuk pemda DKI Jakarta sebagai pemilik mayoritas shareholders dalam bentuk setoran PAD (Pendapatan Asli Daerah). Berdasarkan data Kementerian Dalam Negeri pada APBD 2013, kontribusi PAD non pajak dan retribusi pemprop DKI Jakarta sebesar Rp. 3,252 Trilyun. Dengan total PAD sebesar Rp. 26.670,45 Trilyun, kontribusi PAD non pajak dan retribusi sebesar 12,19\%, termasuk didalamnya shareprofit Badan Usaha Milik Daerah (BUMD) PT Pembangunan Jaya Ancol Tbk. Peraturan Pemerintah nomor 6/2006 tentang pengelolaan barang milik negara/daerah menyatakan bahwa Aset Negara dapat di manfaatkan oleh Badan Usaha, dalam hal ini termasuk aset negara dimana Badan Usaha menjalankan usahanya berdasarkan suatu konsesi yang diberikan, atau aset dibangun oleh suatu Badan Usaha untuk kepentingan Pemerintah dan kemudian dioperasikan oleh Badan Usaha tersebut. Penunjukkan suatu Badan Usaha untuk memanfaatkan aset Negara harus dilakukan melalui proses tender yang kompetitif. Bentuk-bentuk pemanfaatan barang milik negara atau daerah berupa sewa, pinjam pakai, kerjasama pemanfaatan, bangun guna serah (BOT) dan bangun serah guna (BTO). Peraturan Pemerintah nomor 50 tahun 2007 tentang Tata Cara Pelaksanaan Kerjasama Daerah dinyatakan bahwa kerjasama antara pemerintah daerah dengan Badan Usaha harus disetujui oleh Dewan Perwakilan Rakyat Daerah, bila kerjasama tersebut mengakibatkan adanya pemanfaatan aset pemerintah daerah

Tujuan penelitian ini menganalisis kelayakan bisnis properti melalui pola kerjasama pemerintah-swasta dalam pengembangan pusat bisnis seaport-waterfrontcity dengan mengambil studi kasus di area Jembatan Suramadu sisi Surabaya.

Tantangan bisnis properti melalui pola kerjasama pemerintah-swasta khususnya dalam pengembangan seaport-waterfrontcity adalah lemahnya pelayanan perijinan di instansi pemerintah. Laporan Doing Business 2014, Indonesia di posisi ke-120 dari segi tingkat kemudahan berbisnis, terendah dibandingkan 6(enam) negara ASEAN lainnya (Singapura ke1, Malaysia ke-6, Thailand ke-18, Brunei Darussalam ke-59, Vietnam ke-99 dan Filipina ke108) (Bank Dunia \& IFC, 2013). Laporan Doing Business 2012 menunjukkan perbaikan 
prosedur investasi oleh beberapa pemerintah daerah melalui kemudahan dalam mendirikan usaha, mengurus perijinan mendirikan bangunan dan pendaftaran properti (Bank Dunia \& IFC, 2012). Lemahnya perijinan menjadi salah satu faktor yang menjadikan Indonesia rangking ke-2 setelah Rusia dalam Index Korupsi Kelompok Negara G-20 (G20 Watch, 2013). Presiden RI Joko Widodo telah menjanjikan dalam forum APEC 2014 untuk meningkatkan kualitas pelayanan perijinan melalui optimalisasi Unit Pelayanan Terpadu Satu Pintu sehingga pihak swasta dapat dengan mudah dan cepat mengurus administrasi perijinan di instansi pemerintah (APEC, 2014)

\section{METODE PENELITIAN}

Penelitian ini menggunakan metode kualitatif berupa studi kasus di BPWS (Badan Pengembangan Wilayah Surabaya-Madura). Tahap pertama dilakukan pengumpulan data sekunder berupa laporan-laporan terkait pengembangan wilayah Jembatan Suramadu, dilanjutkan dengan pengumpulan data primer berupa wawancara langsung terhadap pihak terkait yang akan mengembangkan wilayah Jembatan Suramadu sisi Surabaya tersebut. Tahap kedua dilakukan analisis kelayakan bisnis properti di wilayah Jembatan Suramadu sisi Surabaya, meliputi analisis Net Present Value (NPV), Payback Period dan Internal Rate of Return (IRR). Tahap ketiga dilakukan analisis kebijakan terkait kerjasama pihak Pemerintah Daerah dengan pihak Swasta dalam pengembangan properti di wilayah Jembatan Suramadu sisi Surabaya.

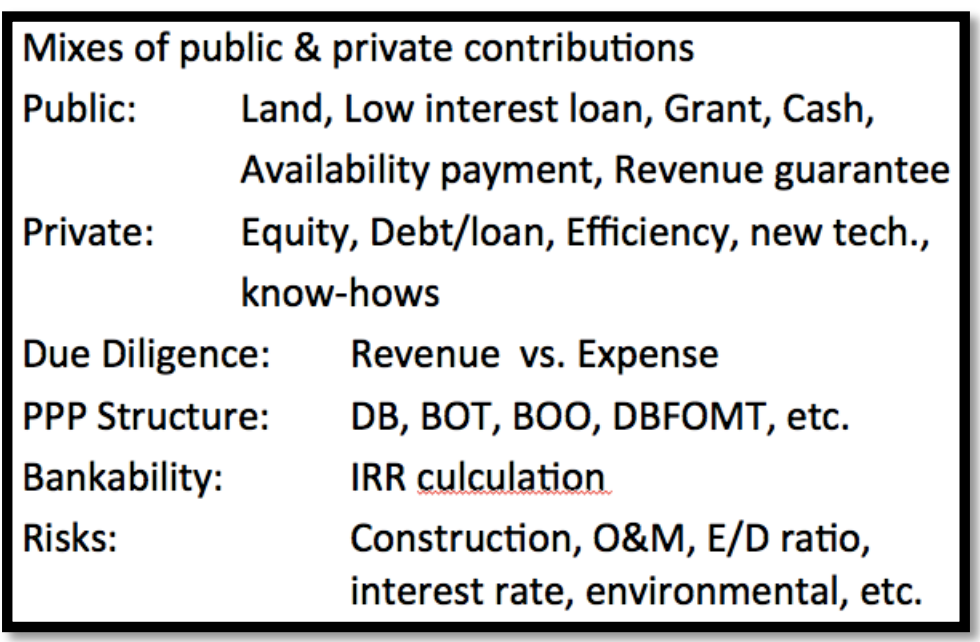

Gambar 1. Model Analisis Kelayakan Proyek PPP Sumber: Santosa, Jatmiko, 2013

Net Present Value (NPV) didapatkan dari total pendapatan yang diperoleh selama umur proyek dikurangi dengan total biaya selama umur proyek dan dihitung berdasarkan nilai sekarang. Sebagai dasar perhitungan akan digunakan tahun dasar tertentu, dengan suku bunga tertentu. Analisa Biaya NPV (Net Present Value) dihitung dengan mendiskonto arus biaya tahunan dan pendapatan secara terpisah, kemudian didapatkan selisih dari kedua jumlah tersebut. Metode ini dirumuskan sebagai berikut:

$\mathrm{NPV}=\mathrm{PV}$ (pendapatan $\mathrm{x}$ faktor diskonto) - PV (biaya $\mathrm{x}$ faktor diskonto)

- Bila NPV bernilai negatif berarti proyek pembangunan tidak menghasilkan keuntungan pada umur ekonomis rencana.

- Bila NPV bernilai positif berarti proyek pembangunan dapat dilaksanakan karena menghasilkan keuntungan pada umur ekonomis rencana. 
- Bila NPV sama dengan nol berarti proyek pembangunan dapat dilaksanakan tetapi tidak menghasilkan keuntungan pada umur ekonomis rencana.

Payback period adalah jangka waktu yang dibutuhkan untuk mengembalikan investasi yang dikeluarkan dengan total nilai sekarang atas arus kas yang dihasilkan.

Internal Rate of Return (IRR) dinyatakan sebagai suatu tingkat suku bunga atau diskonto dimana nilai sekarang dari keuntungan adalah sama besarnya dengan nilai sekarang dari biaya-biaya yang dikeluarkan pada tingkat suku bunga yang dihasilkan. Dengan kata lain IRR merupakan tingkat suku bunga atau diskonto dimana NPV $=0$ atau $\mathrm{BCR}=1.0$.

Metode ini dirumuskan sebagai berikut:

$$
I R R=D f P+\frac{\text { NPVP } x(D f N-D f P)}{\text { NPVp }- \text { NPVn }}
$$

\footnotetext{
dimana,

IRR = Tingkat Pengembalian rata-rata

DfP = Df yang digunakan untuk menghasilkan Net Present Value Positif

DfN = Df yang digunakan untuk menghasilkan Net Present Value Negatif

NPV $p=$ NPV pada diskonto rata-rata positif

NPV $\mathrm{n}=$ NPV pada diskonto rata-rata negatif

Bila IRR > tingkat bunga yang berlaku proyek layak dilaksanakan
}

Seaport-waterfrontcity (kawasan pesisir) merupakan kawasan yang strategis dalam konteks pengembangan wilayah karena karakteristik dan keunggulan komparatif dan kompetitifnya. Pengembangan wilayah merupakan berbagai upaya untuk memacu perekembangan sosial ekonomi, mengurangi kesenjangan antarwilayah, dan menjaga kelestarian lingkugan hidup pada suatu wilayah (Fulyaningtyas, 2009). Salah satu pengembangan kawasan pesisir dapat dilakukan dengan menerapkan konsep waterfront city. Menurut Direktorat Jenderal Pesisir dan Pulau-Pulau Kecil dalam Pedoman Kota Pesisir (2006) mengemukakan bahwa Kota Pesisir atau waterfront city merupakan suatu kawasan yang terletak berbatasan dengan air dan menghadap ke laut, sungai, danau dan sejenisnya. Waterfront city juga dapat diartikan suatu proses dari hasil pembangunan yang memiliki kontak visual dan fisik dengan air dan bagian dari upaya pengembangan wilayah perkotaan yang secara fisik alamnya berada dekat dengan air dimana bentuk pengembangan pembangunan wajah kota yang terjadi berorientasi ke arah perairan. Sebagai bagian dari kawasan pesisir, kota pesisir (waterfront city) memiliki karakteristik sebagai kawasan open acces and multi use yang berpotensi sebagai prime movers pengembangan wilayah lokal, regional, dan nasional, bahkan internasional (Rahmat, 2010).

Central Business District secara umum terdiri dari dua bagian, yaitu: (1) bagian paling inti yang disebut RBD (Retail Business District). Dominasi kegiatan pada bagian ini adalah department stores, smart shops, bangunan perkantoran, clubs, bangunan perbankan, hotels theatres and headquarters of economic, ruang sosial, civic and political life. (2) bagian di luarnya yang disebut WBD (Wholesale Business District). Daerah ini ditempati bangunan yang digunakan untuk kegiatan ekonomi dalam jumlah yang besar seperti pasar, pergudangan (warehouse), gedung penyimpan barang (storage building) (Zaw, Lin, Shwe, Theingi \& Hlaing, Maung, 2014) 


\section{HASIL PENELITIAN}

Badan Pengelola Wilayah Suramadu sejak tahun 2010 telah merencanakan pengembangan area publik yang meliputi wilayah disisi Surabaya $\pm 600 \mathrm{Ha}$, wilayah disisi Madura $\pm 600 \mathrm{Ha}$, kawasan khusus di Pulau Madura $\pm 600 \mathrm{Ha}$ dalam satu kesatuan dengan pelabuhan peti kemas, perumahan dan industri berikut jalan aksesnya yang akan dikembangkan menjadi meliputi pusat perdagangan dan jasa, pusat wisata, permukiman (Rumah Susun dan Apartemen), ruang terbuka (RTH \& RTNH) dan perkantoran pemerintah. Sebagai Kawasan Strategis Ekonomi Provinsi Jawa Timur, kawasan Suramadu sisi Surabaya beberapa area difungsikan sebagai pusat bisnis (Central Business District). Pusat Bisnis direncanakan pada area interchange Kawasan Kaki Jembatan Suramadu sisi Surabaya (KKJS), yaitu pada Blok II B Sub-blok 6, Blok I B Sub-blok 6, Blok III Sub-blok 2, dan Blok IV B Sub-blok 4 dan 7. Direncanakan pengembangan pusat bisnis dengan koefisien dasar bangunan (KDB) sebesar $50 \%$, koefisien luas bangunan (KLB) $1.200 \%$ dengan ketinggian 40 lantai. Penggunaan pada lantai 1-4 direncanakan untuk kegiatan perbelanjaan dengan proporsi bangunan $100 \%$ dari total penggunaan lahan terbangun, pada lantai 5-10 direncanakan untuk kegiatan jasa lainnya dengan proporsi bangunan $60 \%$ dari total penggunaan lahan terbangun, dan pada lantai 10-40 digunakan untuk hunian dengan proporsi bangunan 40\% dari total penggunaan lahan terbangun. Untuk daya tampung kegiatan perbelanjaan digunakan asumsi bahwa kebutuhan ruang untuk pegawai/karyawan sebesar $11 \mathrm{~m} 2$, sedangkan untuk kebutuhan ruang pengunjung adalah $14 \mathrm{~m} 2 /$ jiwa. Untuk daya tampung kegiatan jasa lainnya digunakan asumsi bahwa kebutuhan ruang untuk pegawai/karyawan sebesar $11 \mathrm{~m} 2$, sedangkan untuk kebutuhan ruang pengunjung adalah $28 \mathrm{~m} 2 /$ jiwa. Dan untuk hunian digunakan asumsi bahwa pada setiap unit kamar (1 kamar seluas $150 \mathrm{~m} 2$ ) memiliki daya tampung 2 orang. Total CBD dapat menampung 158.517 jiwa. Pembangian area CBD sebagai berikut: (1) District 1 (Area Office Tower, Commercial-Urban Housing, Urban Housing dan Apartement-Commercial) (2) District 2 (Area Commercial) (3) District 3 (Area Urban Housing dan Community Center) (4) District 4 (Urban Housing dan Commercial). Total luas lahan CBD sebesar 608,278 m2, dengan biaya Pembebasan Lahan CBD senilai Rp. 1,513 Trilyun dan biaya Pembangunan CBD senilai Rp. 36,557 Trilyun. Pelaksanaan pembebasan lahan serta pembangunan fisik CBD dilakukan bertahap maksimal selama 5(lima) tahun.

Analisis dengan HGB 30 tahun dan biaya sewa Rp 500.000,- /m2 per tahun dengan penjualan optimis $100 \%$, penjualan moderat $90 \%$ dan penjualan pesimis $80 \%$. Berdasarkan analisis kelayakan investasi kawasan CBD pada kondisi optimis, menunjukkan hasil yang layak dengan NPV Rp. 19.251.719.084.088, IRR 18,51\%, PI 1,99 dan PBP 11 tahun, sedangkan analisis kelayakan investasi kawasan CBD pada kondisi moderat, menunjukkan hasil yang layak dengan NPV Rp. 13.275.805.960.734, IRR 16,82\%, PI 21,68 dan PBP 13 tahun, dan analisis kelayakan investasi kawasan $\mathrm{CBD}$ pada kondisi pesimis, menunjukkan hasil yang layak dengan NPV Rp. 7.152.755.613.547, IRR 14,34\%, PI 1,37 dan PBP 17 tahun. Berdasarkan analisis kelayakan investasi tersebut, maka pengembangan pusat bisnis di kaki jembatan Suramadu sisi Surabaya layak secara bisnis 


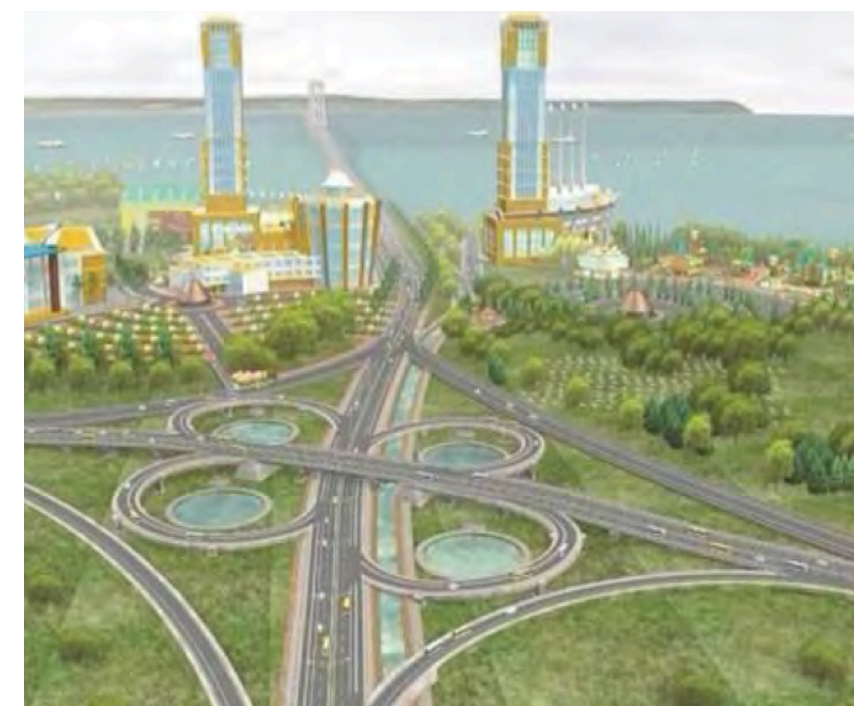

Gambar 2. Pengembangan Properti Area Jembatan Suramadu sisi Surabaya Sumber: Badan Pengembangan Wilayah Suramadu, 2013
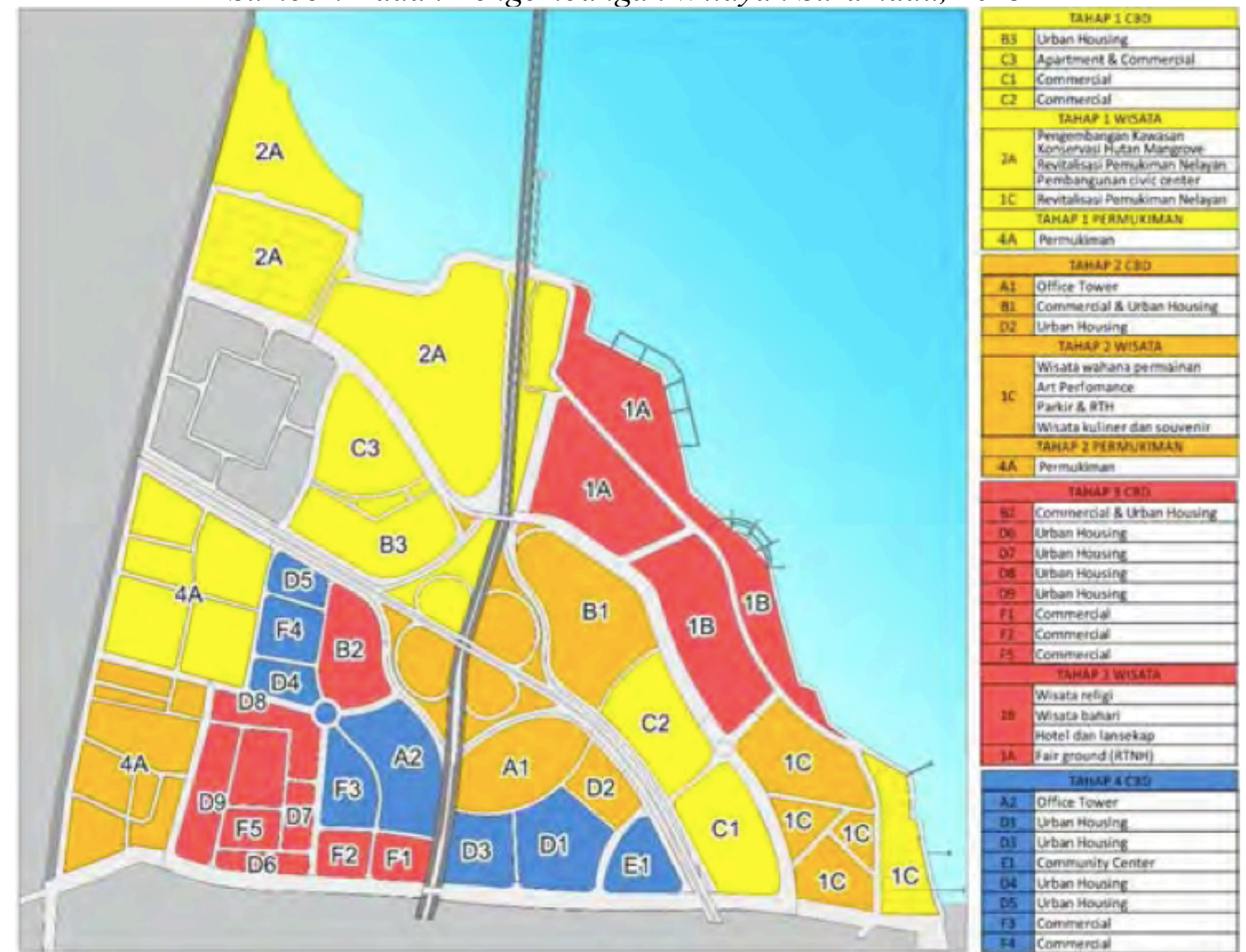

Gambar 3. Plot Area Pengembangan Kawasan Kaki Suramadu sisi Surabaya (KKJSS)

Sumber: Badan Pengembangan Wilayah Suramadu, 2013

Hak Pengelolaan (HPL) muncul sejak tahun 1965 melalui Peraturan Menteri Agraria No. 9 Tahun 1965 tentang Pelaksanaan Konversi Hak Penguasaan Atas Tanah Negara dan Kebijaksanaan Selanjutnya. Badan-badan hukum yang dapat mempunyai Hak Pengelolaan, antara lain Pemerintah Kabupaten/Kota, Perusahaan Umum (Perum) Pembangunan Perumahan Nasional (Perumnas), PT. Pelabuhan Indonesia (Persero), PT. Kereta Api Indonesia (Persero), PT. Angkasa Pura (Persero), Badan Otorita Batam, PD. Pasar Surya Surabaya, PD. Pasar Jaya DKI Jakarta, PD. Sarana Jaya DKI Jakarta, PT. Surabaya Industrial 
Estate Rungkut (SIER), PT. Pasuruan Industrial Estate Rembang (PIER) (Santoso, 2012). Urip Santoso (Santoso, 2012) menyatakan bahwa dalam praktik terdapat berbagai jenis Hak Pengelolaan, yakni:
a) HPL Pelabuhan;
b) HPL Otorita;
c) HPL Perumahan;
d) HPL Pemerintah Daerah;
e) HPL Transmigrasi;
f) HPL Instansi Pemerintah;
g) HPL Industri/Pertanian/Pariwisata/Perkeretaapian.

Terkait rumah susun/Apartemen dalam UU No. 20/2011 tentang Rumah Susun dan Apartement, dinyatakan bahwa rumah susun dapat di bangun di atas tanah hak milik; hak guna bangunan atau hak pakai atas tanah negara; dan hak guna bangunan atau hak pakai di atas hak pengelolaan (Pasal 17 UU No.20/2011). Bila tanah tempat berdirinya rumah susun merupakan tanah wakaf sewa atau tanah negara /pemda atau tanah swasta yang disewa maka perlu diperhatikan Perjanjian tertulis sekurang-kurangnya memuat:

a) Hak dan kewajiban penyewa dan pemilik tanah;

b) Jangka waktu sewa atas tanah;

c) Kepastian pemilik tanah untuk mendapatkan pengembalian tanah pada akhir masa perjanjian sewa.

Bila tanah tempat berdirinya rumah susun milik negara/pemda maupun swasta, maka pemilik rumah susun perlu bukti surat dari pengelola rumah susun yang menyatakan bahwa bila masa Sertifikat Hak Guna Bangunan (SHGB) rumah susun telah habis masanya 30 tahun akan dapat diperpanjang selama 20 tahun lagi dan sekaligus berisikan bahwa rumah susun tersebut dapat dijadikan objek Hak Tanggungan (contohnya SK Menteri Sekretaris Negara No. 401/M.Sesneg/D-4/07/2008 yg dipergunakan untuk apartemen Kemayoran) (Santoso, 2012)

\section{KESIMPULAN}

a) Berdasarkan analisis kelayakan investasi kawasan CBD pada kondisi optimis, menunjukkan hasil yang layak dengan NPV Rp. 19.251.719.084.088, IRR 18,51\%, PI 1,99 dan PBP 11 tahun, sedangkan analisis kelayakan investasi kawasan CBD pada kondisi moderat, menunjukkan hasil yang layak dengan NPV Rp. 13.275.805.960.734, IRR 16,82\%, PI 21,68 dan PBP 13 tahun, dan analisis kelayakan investasi kawasan CBD pada kondisi pesimis, menunjukkan hasil yang layak dengan NPV Rp. 7.152.755.613.547, IRR 14,34\%, PI 1,37 dan PBP 17 tahun.

b) Berdasarkan analisis kelayakan bisnis properti tersebut, pusat bisnis di kaki jembatan Suramadu sisi Surabaya layak secara bisnis dan layak untuk dikerjasamakan antara Pemerintah Daerah-Swasta.

c) Berdasarkan analisis legalitas lahan properti, pusat bisnis di kaki jembatan Suramadu sisi Surabaya layak secara bisnis meskipun statusnya adalah Hak Pengelolaan (HPL) dengan pola Sertifikat Hak Guna Bangunan (SHGB) masa 30 tahun dapat diperpanjang 20 tahun dan selanjutnya dapat diperpanjang sesuai kesepakatan bersama antara pihak Pemerintah dengan Swasta (Pengelola Bangunan) 


\section{DAFTAR PUSTAKA}

1. Badan Koordinasi Penanaman Modal (2014) Realisasi Penanaman Modal PMDN-PMA Q4-2014, Jakarta, bkpm.go.id

2. Bank Dunia \& IFC (2012) Doing Business di Indonesia: membandingkan kebijakan usaha di 20 kota dan 183 perekonomian, The World Bank, Washington DC USA

3. Bank Dunia \& IFC (2013) Doing Business 2014: Understanding Regulations for Small and Medium-Size Enterprises, The World Bank, Washington DC USA

4. Bank Indonesia (2014) Perkembangan Properti Komersial-Triwulan III 2014, Jakarta, bi.go.id

5. Boston Consulting Group (2013) Asia's Next Big Opportunity: Indonesia's Rising MiddleClass and Affluent Consumers, bcg.com

6. Bursa Efek Indonesia (2013) Performance Summary PT Pembangunan Jaya Ancol Tbk, idx.co.id

7. Bursa Efek Indonesia (2014) IDX Statistics 2014, BEI Research Divisions, idx.co.id

8. Direktorat Jenderal Pesisir dan Pulau-Pulau Kecil (2006) Pedoman Kota Pesisir, Kementerian Kelautan dan Perikanan, Jakarta

9. Fulyaningtyas, Septerina (2009) Arahan Pengembangan Pantai Timur Surabaya Sebagai Kawasan Ekowisata, ITS: Jurusan PWK, Surabaya

10. Kementerian Dalam Negeri (2010) Neraca APBD 2010, Kementerian Dalam Negeri RI, Jakarta

11. Kementerian Dalam Negeri (2013) Postur APBD Tahun Anggaran 2013, Kementerian Dalam Negeri RI, Jakarta

12. Peraturan Pemerintah no. 50 tahun 2007 tentang Tata Cara Pelaksanaan Kerjasama Daerah

13. Rahmat, Adipati (2010) Jakarta Waterfront City, adipatirahmat.wordpress.com

14. Santosa, Jatmiko (2013) Public Private Partnership in Indonesia \& ASEAN-East Java Case Study, PT Sarana Multi Infrastruktur (Persero), Jakarta

15. Santoso, Urip (2013) Hukum Agraria; Kajian Komprehensif, Jakarta

16. The Economist (2015) Investing Into Asia's Reform Landscape: Asia Business Outlook Survey 2015, The Economist Corporate Network

17. Tiffin R (1999) Practical Techniques for Effective Project Investment Appraisal, Hawksmere PLC

18. UNCTAD United Nations Conference on Trade and Development (2013) World Investment Prospects Survey 2013-2015, United Nations, New York and Geneva

19. Undang Undang no. 22 Tahun 1999 \& UU no.34 tahun 2004 tentang Otonomi Daerah

20. Zaw, Lin, Shwe, Theingi \& Hlaing, Maung (2014) Studies of the Status of Central Business District Area (CBD) in Yangon, Myanmar, International Journal of Emerging Technology and Advanced Engineering, Volume 4, Issue 5, May 2014 